\title{
Relationship of Academic SE to Self-Regulated Learning, SI, Test Anxiety and Academic Achievement
}

\author{
Shafiq Ahmad \\ Doctoral Researcher, University of Education \\ College Road, Township, Lahore, Pakistan \\ E-mail: shafiqahmad58@ hotmail.com \\ Dr Ashiq Hussain \\ Controller Examinations, University of Education \\ College Road, Township, Lahore, Pakistan \\ E-mail: drashiq10@yahoo.com \\ Muhammad Azeem (Corresponding author) \\ Assessment Expert, Punjab Education Assessment System (PEAS) \\ University of Education \\ College Road, Township, Lahore, Pakistan \\ E-mail: knowledge_jhumra@yahoo.com
}

Received: November 18, 2011 Accepted: December 15, 2011 Published: March 1, 2012

doi:10.5296/ije.v4i1.1091

URL: http://dx.doi.org/10.5296/ije.v4i1.1091 


\title{
Macrothink
}

\begin{abstract}
The study was conducted to analyse the relationship of academic self-efficacy to self-regulated learning, school identification, test anxiety and academic achievement at secondary school level. Another purpose was to examine whether self-efficacy and school identification predict academic achievement or not. Four instruments were administered to a sample of 426 students of Grade 10 (205 boys, and 221 girls). Results revealed significant correlation between the variables. Strongest relationship was found between students' academic self-efficacy and self-efficacy for self-regulation. Self-efficacy beliefs at academic domain level were found contributing significantly to the prediction of academic achievement. Significant gender differences were not found on measures of self-efficacy beliefs at academic domain level, school identification, and anxiety. Girls' academic achievement was found better than the boys' achievement. Boys were reported better than girls on measure of self-efficacy for self-regulated learning.
\end{abstract}

Keywords: Self-Efficacy (SE) beliefs, self-regulated (SR) learning, School identification (SI) test anxiety 


\section{Introduction}

Researchers have given due attention to SE beliefs in educational research (Pintrich \& Schunk, 1996) and researchers (e.g., Bandura, 1997; Pajares, 1996a; Pajares \& Schunk, 2001; Usher \& Pajares, 2006; Zimmerman, 1989) have reported that students' beliefs in their abilities to achieve desired goals strongly influence academic achievement. Relationship of SE has widely been investigated with SR (see, Usher \& Pajares, 2006; Zimmerman, 1989; Zimmerman \& Martinez-Pons, 1990), motivation (see, Bandura \& Schunk, 1981; Cheong, Pajares \& Oberman, 2004; Mills, Pajares \& Herron, 2007; Pajares, 2001; Schunk, 1984, Stevens, Olivarez, Lan \& Tallent-Runnels, 2004), SI (see, Finn \& Frone, 2004), and anxiety (see, Cooper \& Robinson, 1991; Mills, Pajares \& Herron, 2006).

In accordance with Bandura's (2006) description, perceived efficacy is the judgment of capability to execute given types of performance. Students having beliefs in their capabilities to achieve take interest in academic related activities, put in concerted efforts, set challenging goals, and show resolve in taxing situations (Bandura, 1997; Pajares, 1996a, Usher \& Pajares, 2006). School success is primarily dependent on one's confidence in academic capabilities as Pajares (2007a) pointed out that academic failures and deteriorating school interest are not due to lack of capabilities but because of low SE perceptions.

SE beliefs. People's belief about their capabilities to organize and perform required action to achieve pre-determined goals (Bandura, 1997). "Academic SE reflects the extent to which students believe that they can successfully perform in school" (Finn \& Frone, 2004, p.118).

SE beliefs are strong predictors of students' accomplishments (Bandura, 1986, 1997). SE beliefs determine the course of action and consequently influence academic performance (Pajares, 1996b).

Social cognitive theorists are of the view that beliefs in capabilities to perform well to accomplish assigned tasks, determine academic motivation and performance (Pajares \& Miller, 1997). Level of motivation depends on what people believe and not on what is actually true (Bandura, 1997). That is why, people sometime exhibit behaviour which is entirely different from what they truly are, and often perform differently despite having more or like the same level of knowledge and expertise (Pajares \& Schunk, 2001, Pajares, 2002a;).

Researchers have found positive association between SE beliefs and academic achievement. Pajares and Graham (1999) found SE beliefs significantly correlated to academic performance $(\mathrm{r}=.57, \mathrm{p}<.0001)$, and self-regulated learning $(\mathrm{r}=.53, \mathrm{p}<.0001)$. Results of study conducted by Mills, Pajares and Herron (2007) found strong association between sense of grade SE and SR $(r=.42, \mathrm{p}<.001)$, and final course grade $(\mathrm{r}=.24, \mathrm{p}<.001)$.

$\boldsymbol{S E}$ for $\boldsymbol{S R}$ is one's perceived ability to use the appropriate strategies to plan, monitor, and complete a task (Bandura, 1997). While elaborating SR, Bandura (1991) contends that people anticipate likely consequences; set goals; and plan courses of action to achieve their goals. Exercise of forethought, motivate and guide their actions. High sense of regulatory efficacy 
helps build a strong sense of cognitive efficacy and elevates academic related goals (Zimmerman, Bandura \& Martinez-Pons, 1992).

Zimmerman and colleagues found SE for SR as contributing factor to academic achievement (Zimmerman \& Bandura, 1994; Zimmerman \& Martinez-Pons, 1990). Results of study conducted by Mills, Pajares and Herron (2007) found strong association between perceived SE for SR and sense of grade SE $\quad(r=.42, p<.001)$, and final course grade $(r=.23, p$ $<.001)$. Usher and Pajares (2006) found SE for SR significantly associated with SE ( $\mathrm{r}=.70$, $\mathrm{p}<.001)$, and final grade $(\mathrm{r}=.32, \mathrm{p}<.001)$.

Test anxiety represents the extent to which a student experience fear, apprehensiveness, nervousness, panic restlessness and tension while even thinking of an upcoming test or examination. Anxiety can also be seen as a product of uncertainty, uncertainty about an upcoming event or situation (Craig, Brown \& Baum, 2000). Bandura (1997) opines that people experience anxiety when they perceive a situation as dangerous and beyond their control.

Researchers (Bandura, 1997; Britner \& Pajares, 2001, 2006, Pajares, 1996b) found stronger relationship between students' perceived efficacy and academic achievement than levels of anxiety.

SI represents the bond which is formed between students and school (Finn \& Frone, 2004). Interest in schooling is one of the factors that contribute significantly to the academic achievement (Adeyemo, 2005). Those who are confident to master academic skills and to regulate their own learning are more social and enjoy greater popularity than those who suffer with self-doubts (Bandura, 1993). Children with less favourable attitude toward school exhibit decreased level of academic performance (Crawl, Kaminsky \& Podell, 1997). Students' interest in school activities depends on congeniality of the environment (Schunk \& Pajares, 2002). Researchers have found strong association between students' attachment with school and academic success (Goodenow, 1993; Liska \& Reed, 1985; Newmann, 1981; cited in Finn \& Frone, 2004).

Gender differences. Researchers reporting gender differences in SE, reported boys confidence level in math and science abilities much higher than the girls (Britner \& Pajares, 2001; Pajares, 2002b). Conversely, female students were reported having higher level of SE in arts and language (Pajares \& Valiante, 2006; cited in Mills, Pajares, \& Herron, 2007), and in writing capabilities as compared to male students (Pajares, et, al., 1999; Pajares \& Valiante, 1997, 1999, 2001; Wigfield, Eccles, Maclver, Reuman, \& Midgley, 1991; Wigfield, Eccles, \& Pintrich, 1996; cited in Pajares, 2007b).

Studies on SE and academic achievement are available in abundance but most of the researches considered specific academic domain to measure efficacy beliefs of students and analysed relationship with academic achievement and other variables. Studies on academic SE frequently involve particular problem-solving situations within a related academic domain (see, Pajares \& Graham, 1999, Schunk, 1996). According to Bong (2002), SE research has been context-specific. Nonetheless, efficacy beliefs have also been assessed in reference to 
specific subject areas or general school leaning when researchers attempted to predict more general-level outcomes (Bandura, Barbaranelli, Caprara \& Pastorelli, 1996; Bong, 2002; Pajares, 2001).

Pajares (2001) found positive correlation between academic achievement and motivation variables at academic domain level. Bong $(1998,2004)$ found that students' efficacy perceptions generalize beyond the boundary of a single, specific task.

This study was conducted to assess efficacy beliefs of students' at academic domain level. This study assessed SE of students' at academic domain level while there was a gap of two weeks between administration of questionnaire and actual performance of students' in their examination. Purpose was to investigate whether students' efficacy beliefs at academic domain level contribute in predicting academic achievement when they are prepared for the exam which has been scheduled to be held after two weeks from the day of administering the questionnaire. This study also examined the relationship of students' efficacy beliefs to their self-regulated learning strategies, SI, and test anxiety with intent to know whether the findings of this study are consistent with the previous studies. An effort was also made to explore the gender differences.

Academic achievement of students was determined from result of exam conducted by respective schools. Question papers for each subject were prepared centrally. Schools conducted the exam, prepared and compiled the results. Results of participants of this study were provided to the researcher by respective schools. SE beliefs and other variables were assessed prior to exam. Students were told to rate their confidence regarding expected performance in forthcoming examination. Scores on all variables were then correlated. Effort was made to assess the assertion made by Pajares (2002b) that students' academic performances rely on their beliefs of what they have achieved and can achieve.

\section{Objectives}

The objectives of this research were to:

1) Find the evidence of the influence of SE on other variables including school achievement.

2) To see as to what extent, SE at academic domain level is interrelated with other variables.

3) To examine whether SE predicts academic achievement when questionnaire is administered two weeks prior to conduct of examination.

4) To study the influence of SI in predicting the academic achievement.

\section{Hypotheses}

In the pursuit of stated objectives, following hypotheses were tested:

$\mathrm{H}_{1}$ : SE will correlate positively with $\mathrm{SR}$, SI, academic achievement and negatively with anxiety. 
$\mathrm{H}_{2}$ : SE will make an independent contribution to the prediction of academic achievement.

$\mathrm{H}_{3}$ : SI will contribute in predicting academic achievement.

\section{Method}

\subsection{Participants and Procedure}

The sample of this study was consisted of 426 students (221 girls and 205 boys) belonged to four English medium schools located in Lahore (two schools each for boys and girls). These schools impart education up to secondary school level and participants of this study were students of Grade - 10. Participants belonged to middle to lower middle-income families and their ages ranged from 15 to 17 years. Participants had completed their course work and were to appear in their send up examination. Instruments were administered two weeks before the examination and assessment was made with scales previously used by researchers. Marks achieved by the students in their exam were taken as their academic achievement. Examination was conducted by respective school. Schools compiled and provided exam results of participating students to researcher.

\subsection{Instrumentation}

Perceived SE. Children's SE Scales by Bandura, (2006) were considered and subscales namely, "SE for academic achievement", and, "SE for self-regulated learning" were selected to use in this study. First scale was to measure students' perception of their capability to achieve in examination and was comprised on eight items. Students were to respond on a Likert-type scale ranging from 0 to 100 by noting down their response on questions like, how well they could learn subjects of mathematics, physics, chemistry, social studies, Islamic studies, English and Urdu. Coefficient alpha reliability ranging from .69 to .85 has been reported previously (see Britner \& Pajares, 2006; Pajares, 2001; Valiante \& Pajares, 1999; Zimmerman, Bandura \& Martinez-Pons, 1992). However, alpha coefficient obtained in this study was .82 .

SE for self-regulated learning scale comprised on seven items. The scale measured students' perception of their ability to use self-regulating strategies in academic tasks. Participants were to respond on a Likert-type scale ranging from 0 to 100 by noting down their response on questions about timely completion of homework and level of motivation when there are other interesting things to do. Cronbach's alpha values reported previously ranged from .78 to .87 (see Britner \& Pajares, 2006; Mills, Pajares \& Herron, 2007; Pajares, 1996a, 2001, 2007a). For present study, alpha value was .77.

SI represents the level of students' attachment with school, their feelings, and sense of valuing and belonging in school (Finn \& Frone, 2004). SI was measured with 13-item Identification with School Questionnaire, adapted from Finn and Frone. Participants were to respond on a four-point Likert type scale. In Finn and Frone study, alpha reliability was .83, and, alpha reliability in this study was .82 .

Test anxiety represents the extent to which a student experience fear, apprehensiveness, nervousness, panic restlessness and tension while even thinking of an upcoming test or 
examination. Britner and Pajares's (2006) Science Anxiety Scale (SAS) was adapted to measure test anxiety. The wordings of the items were altered to make them reflect test anxiety. The 12-item test anxiety scale asked students to consider statements (e.g., I worry that I will get poor grades in most of the subjects) and respond on a 6-point scale ranging from definitely false to definitely true. Cronbach's alpha coefficient for previous studies ranged from .63 to .91 (see Britner \& Pajares, 2001, 2006). Coefficient alpha reliability for this study was .66 .

Academic performance was assessed with participants' result of their send up examination. Duration between participants' assessed SE and assessed performance was not less than two weeks. Respective schools conducted the examination and provided students' achieved marks to this researcher.

\section{Data Analyses}

Pearson ' $r$ ' was used to examine the relationship between academic SE, SR, test anxiety, SI and academic achievement. Hierarchical multiple regression was conducted to analyse the contribution of academic SE to the prediction of academic achievement. I chose hierarchical regression to explore the role of SE which has previously been demonstrated to the prediction of students' accomplishments. In the first step, percentages of marks obtained by students' in examination were taken as dependent variable, whereas, academic SE, SE for SR, and test anxiety were taken as independent variables. First step tested whether academic SE would predict achievement when controlling SE for self-regulated learning, and test anxiety.

SI was added in the second step of regression analysis to evaluate its impact on academic achievement when motivation constructs known for predicting academic accomplishment were controlled.

\section{Results}

Means, standard deviations, and inter-correlation are given in Table 1. Correlation coefficients were computed among the academic SE, SE for SR, SI, test anxiety, and academic achievement.

Table 1. Descriptive statistics and inter-correlations among the variables $(n=426)$

\begin{tabular}{|c|c|c|c|c|c|c|c|}
\hline Variables & Mean & $S D$ & 1 & 2 & 3 & 4 & 5 \\
\hline 1. Academic SE & 59.2 & 9.9 & -- & & & & \\
\hline 2. $\mathrm{SR}$ & 49.5 & 8.6 & .70 & -- & & & \\
\hline 3. SI & 39.6 & 6.5 & .54 & .45 & -- & & \\
\hline 4. Test anxiety & 38.0 & 9.1 & -.40 & -.40 & -.33 & -- & \\
\hline $\begin{array}{l}\text { Academic } \\
\text { achievement }\end{array}$ & 61.0 & 12.1 & .59 & .51 & .38 & -.38 & -- \\
\hline
\end{tabular}

$$
\mathrm{p}<.01
$$

As shown in Table 1, academic SE was significantly correlated with other variables ranging from -.40 to .70 . The strongest correlation was found between academic SE and SE for SR. 


\section{Ml Macrothink}

Nonetheless, test anxiety was found having significant negative correlation with academic SE, SE for SR, SI and academic achievement.

To check for gender differences, independent-sample $t$ tests were conducted and no gender differences were found in academic SE, SI and test anxiety. Nevertheless, gender differences in students' SE for SR and academic performance were significant. Male students were found having stronger sense of $\mathrm{SE}$ for $\mathrm{SR}(\mathrm{M}=50.6, \mathrm{SD}=8.5)$ as compared to female students $(\mathrm{M}$ $=48.5, \mathrm{SD}=8.5), t(424)=-2.59, \mathrm{p}<.01$. Female students recorded better performance in examination $(\mathrm{M}=62.4, \mathrm{SD}=12.0)$ than male students $(\mathrm{M}=59.5, \mathrm{SD}=12.1), \mathrm{t}(424)=2.47$, $\mathrm{p}<.01$.

Table 2. Standardised Regression Coefficients Predicting students' achievement from Hierarchical Multiple Regression Models for Variables $(n=426)$

\begin{tabular}{lcc}
\hline & Model 1 & Model 2 \\
\cline { 2 - 3 } Academic SE & $.431^{* *}$ & $.411^{* *}$ \\
SR & $.150^{*}$ & $.144^{*}$ \\
Test anxiety & $-.146^{*}$ & $-.140^{*}$ \\
\hline SI & & .048 \\
\hline $\mathrm{R}^{2}$ & $.388^{* *}$ & $.390^{* *}$ \\
\hline Change in $\mathrm{R}^{2}$ & & .002 \\
\hline${ }^{\mathrm{p}}<.01, * * \mathrm{p}<.001$ & &
\end{tabular}

Results suggest significant relationship between independent variables and academic achievement, $\mathrm{R}^{2}=.38, \mathrm{~F}(3,422)=89.07, \mathrm{p}<.001$, and accounted for $38 \%$ of the variance. SE was the strong predictor of academic achievement $(\beta=.43)$. A significant relationship was also found between SE for SR and academic achievement $(\beta=.15)$. Results show that test anxiety negatively influenced academic achievement $(\beta=-.15)$.

Results suggest that students' judgment of their capabilities to attain designated types of performances is more predictive of their success at secondary school level. Results also suggest that secondary school students' perceived ability to perform in academic situations and use of suitable strategies to plane, evaluate and achieve designated types of goals are predictive of their academic achievement.

Second step of regression analyses examined the likely contribution towards SI to the prediction of academic achievement. Significant relationship was found between combination of SE, test anxiety, SE for SR and academic SE; and, academic achievement, $\mathrm{R}^{2}=.39, \quad \mathrm{~F}$ $(4,421)=67.1, \mathrm{p}<.001$, but non-significant increase $(0.2 \%)$ in $\left.\mathrm{R}^{2}, \mathrm{~F}(4,421)=67.1, \mathrm{p}=292\right)$ shows that SI added no incremental variance to first model. Results suggest that identification with school does not predict achievement at secondary school level.

\section{Discussion}

One of the objectives of the study was to examine whether SE at academic domain level correlate with other variables in this study or otherwise when students' beliefs are assessed 
two weeks prior to examination. Although results of numerous studies conducted in educational settings different from those existing in Pakistan have reported significant correlation of SE with SE for SR, SI and academic anxiety, but in most studies, question papers or subject contents related to a particular academic domain were shown to the students and then they were asked to complete a questionnaire describing as to how confident they were to solve those problems. After assessing beliefs of students in their capabilities to solve problems, they were given the problems to solve. Performance of students was then correlated with achievement. However, this study is different from previously conducted studies as SE beliefs of students were assessed two weeks prior to their examination and were correlated with other variables along with their achievement in examination. Results of this study were found consistent with other studies as academic SE was significantly correlated with SE for SR, SI, and academic achievement. Test anxiety was found negatively correlated with academic SE, SE for SR and academic achievement. Same results have also been reported in previous studies.

Another purpose for conducting this research was to examine whether students' academic SE would predict their achievement in examination when there is a gap of few days (two weeks in present study) between assessment of SE beliefs and students performance in examination. It was found that students' efficacy beliefs at academic domain level contributed significantly in the prediction of academic achievement. Results reveal that students who perceived themselves capable to perform did experience success. Results support Bandura's (1986, 1997) contention that results people contemplate is dependent on their judgement of whether they are capable to achieve or not.

Various studies have proposed the possibility to enhance the SE beliefs through various techniques and it has been reported that significant enhancements in SE beliefs effect performance. Pajares, (2002b) suggests to parents and teachers to let the students know that success is dependent on beliefs, aspirations, and unflinching efforts, and not on gender or social factors. Teachers should make efforts to enhance students' SE beliefs as these help students perform well in taxing and demanding situations.

Knowledge of self assists in determining the level of personal efficacy. Pajares and Urdan (2006) urged the teachers to develop and enhance self-beliefs through fostering of the sources of SE. Schunk, (1983) suggests to provide feedback on regular basis to enhance SE of students. Schunk (1987) is of the view that students belief in their capabilities gets stronger and they work harder when teachers help them realize that the success they achieve is due to their consistent efforts.

Positive correlation between students' sense of efficacy and SR supports Bandura's (1986, 1997) contention that efficacious students devise more appropriate strategies for the accomplishments of tasks. Researchers have found that self-regulatory processes are teachable (Mills, Pajares \& Herron, 2007). Pajares (2002b) recommends to teachers to find out as to how much confident their students are in formulating and following self-regulatory strategies. If needed, try and modify students' perceptions. Teachers in Pakistan are required to be trained in identifying self-beliefs of students so to enable them to work for the 
enhancement of SE beliefs as well guide their students in formulating appropriate self-regulating strategies.

Negative correlation of test anxiety with other variables suggests that higher level of test anxiety were related to lower level of attainments, lower level of efficacy beliefs, and lower level of SE for SR. Betz (1978) found negative correlation between math anxiety and accomplishment. For better performance at secondary school level, emotional states of students need to be regulated. Anxiety level of students can be reduced by enhancing the level of SE beliefs. This study suggests that students' performance can be enhanced by regulating level of anxiety, increasing academic SE, and SE for SR.

SI was not found contributing significantly in the prediction of academic achievement but was found significantly correlated with SE, SE for SR and achievement. This relationship suggests that school staff and parents should work together for improvement of association between school and students. SI can be improved by paying due attention to students' problems, encouraging students' classroom participation, and engaging students in extracurricular activities.

Interpretation of implications cannot be separated from potential limitations. One of the limitations of this study as viewed by the researchers in other studies as well is the information gathered through self-report instruments. Researchers are of the opinion that instruments assessing participants' feelings and views do not always provide accurate information. Participants may not report what is true but what they believe is expected from them (Mills, Pajares \& Herron, 2006). Another limitation was students' academic achievement, as it was assessed from results provided by the respective schools after conducting examination. Papers were marked by different teachers at different schools. Marking pattern of teachers belonging to different school might have caused dissimilar results. Participants in this study were secondary level students from urban area. Schools imparting instruction in English language were considered so that the participants comprehend the language of the questionnaire. Participants of this study belonged to middle or lower middle-income families. As such, they do not represent the majority of Pakistani students belonged to lower income families studying in public schools of urban or rural areas where language of instruction is Urdu. Therefore, results may not be generalized to other populations

Despite limitations, the study is expected to generate interest in Pakistani researchers to examine various aspects related to efficacy beliefs of students and suggest various measures to enhance self-beliefs. I believe that translation of questionnaire into Urdu language and selection of sample from public schools located in urban as well as rural areas would enhance the scope for generalizing the findings of this study.

\section{References}

Adeyemo, D. A. (2005). Parental involvement, interest in schooling and school environment as predictor of academic SE. Electronic Journal of Research in educational Psychology 5 - 
3(1), 163-180. Retrieved on March 30, 2006, from http://www.investigation.psicopedagogica.org

Baker, S. C., \& Maclntyre, P. D. (2003). The role of gender and immersion in communication and second language orientation [Electronic version]. Language Learning, 53, 65-96. http://dx.doi.org/10.1111/0023-8333.00224

Bandura, A. (1977). SE: Toward a unifying theory of behavioural change. Psychological Review, 84, 191-215. http://dx.doi.org/10.1037/0033-295X.84.2.191

Bandura, A. (1986). Social foundations of thought and action: A social cognitive theory. Englewood Cliffs, NJ: Prentice Hall.

Bandura, A. (1991). Social cognitive theory of SR [Electronic version]. Organizational Behaviour and Human Decision Processes, 50, 248-287. http://dx.doi.org/10.1016/0749-5978(91)90022-L

Bandura, A. (1993). Perceived SE in cognitive development and functioning. Educational Psychologist, 28, 117-148. http://dx.doi.org/10.1207/s15326985ep2802_3

Bandura, A. (2006). Guide for constructing SE scales. In : Fank Pajares \& Tim Urdan (ed.). SE Beliefs of Adolescents. Greenwich, CT: Information Age Publishing.

Bandura, A., \& Schunk, D. H. (1981). Cultivating competence, SE, and intrinsic interest through proximal self-motivation [Electronic version]. Journal of Personality and Social Psychology, 41(3), 586-598. http://dx.doi.org/10.1037/0022-3514.41.3.586

Bandura, A., Barbaranelli, C., Caprara, G. V., \& Pastorelli, C. (1996). Multifaceted impact of self-efficay beliefs on academic functioning. Child Development, 67, 1206-1222. http://dx.doi.org/10.2307/1131888

Bandura. A. (1997). SE: The exercise of control. New York: Freeman.

Betz, N. E. (1978). Prevalence, distribution, and correlates of math anxiety in college students. Journal of Counseling Psychology, 25(5), 441-448. http://dx.doi.org/10.1037/0022-0167.25.5.441

Bong, M. (1998). Effects of scale differences on the generality of academic SE judgments. (Report No. TM 028941). San Diego: American Educational Research Association. (ERIC Document Reproduction Service No. ED 422379).

Bong, M. (2002). Stability and structure of SE, task value, and achievement goals and consistency of their relations across specific and general contexts and across the school year. (Report No. TM 034561). New Orleans, LA: American Educational Research Association. (ERIC Document Reproduction Service No. ED 470665).

Bong, M. (2004). Academic motivation in SE, task value, achievement goal orientations, and attributional beliefs. The Journal of Educational Research, 97 (6), 287-298. http://dx.doi.org/10.3200/JOER.97.6.287-298 
Britner, S. L., \& Pajares, F. (2001). Efficacy beliefs, motivation, race and gender in middle school science. Journal of Women and Minorities in Science and Engineering, 7, 271-285.

Britner, S. L., \& Pajares, F. (2006). Sources of science SE beliefs of middle school students [Electronic version]. Journal of Research in Science and Teaching, 43(5), 485-499. http://dx.doi.org/10.1002/tea.20131

Cheong, Y. F., Pajares, F., \& Oberman, P. S. (2004). Motivation and academic help-seeking in high school computer science. Computer Science education, 14(1), 3-19. http://dx.doi.org/10.1076/csed.14.1.3.23501

Cooper, S. E., Robinson, D. A. G. (1991). The relationship of mathematics SE beliefs to mathematics anxiety and performance. Measurement and Evaluation in Counseling and Development, 24(1). [Online] Retrieved on June 16, 2006, from http://web115.epnet.com/citation.asp?tb=1\&_ug=sid+2E439E7E\%2DF487\%2D452\% 2DB41D\%2D484266FB6FBC

Craig, K. J., Brown, K. J., \& Baum, A. (2000). Environmental Factors in the Etiology of Anxiety. Retrieved April 1, 2006 from http://www.acnp.org/g4/GN401000127/CH125.html

Crowl, T. K., Kaminsky, S., \& Podell, D. M. (1997). Educational psychology, windows on teaching. New York: Brown \& Benchmark.

Finn, K. V., \& Frone, M. R. (2004). Academic performance and cheating: Moderating role of SI and SE. The Journal of Educational Research, 97(3), 115-122. http://dx.doi.org/10.3200/JOER.97.3.115-121

Martocchio, J. J. (1994). Effects of conceptions of ability on anxiety, SE and learning in training. Journal of Applied Psychology, 79(6). [Online] Retrieved on April 2, 2006, from http://comment.apa.org/journals/apt/79/6/819

Mills, N., Pajares, F., \& Herron, C. (2006). A reevaluation of the role of anxiety: SE, anxiety and their relation to reading and listening proficiency [Electronic version]. Foreign Language Annals, 39, 276-293. http://dx.doi.org/10.1111/j.1944-9720.2006.tb02266.x

Mills, N., Pajares, F., \& Herron, C. (2007). SE of college intermediate French students: relation to achievement and motivation [Electronic version]. Language Learning, 57(3), 417-442. http://dx.doi.org/10.1111/j.1467-9922.2007.00421.x

Pajares, F., \& Miller, M, D. (1997). Mathematics SE and mathematical problem solving: implications of using different forms of assessment. Journal of Experimental Education, 65 (3). [Online] Retrieved on June 16, 2006 from http://web115.epnet.com/citationasp?tb=1\&_ug=sid+2E439E7E\%2DF487\%2D4529\%2DB4 1D\%2D484266FBC\%40sessionmgr3+dbs+eric+cp+1+OBAO\&_us=mh

Pajares, F., \& Schunk, D. H. (2001). Self-beliefs and school success:

SE, self-concept, and school achievement. In: R. Riding \& S. Rayner (Eds.), Perception (239-266). London: Alex Publishing. [Online] Retrieved on March 27, 2006 from http://www.des.emory.edu/mfp/PajaresSchunk2001.html 
Pajares, F. (1996a). SE beliefs in academic settings. Review of Educational Research, 66 (4). 543-578. [Online] Retrieved on March 27, 2006. from http://des.emory.edu/mfp/PajaresSE1996.html

Pajares, F. (1996b). SE beliefs and mathematical problem-solving of gifted students [Electronic version]. Contemporary Educational Psychology, 21, 325-344. http://dx.doi.org/10.1006/ceps.1996.0025

Pajares, F. (2001). Toward a positive psychology of academic motivation. The Journal of Educational Research, 95(1). 27-35. http://dx.doi.org/10.1080/00220670109598780

Pajares, F. (2002a). Overview of social cognitive theory and of SE. [Online] Retrieved on March 30, 2006, from http://www.des.emory.edu/EDUCATION/mfp/eff.html

Pajares, F. (2002b). Gender and perceived SE in self-regulated learning. Theory into Practice, 41, 116-125. http://dx.doi.org/10.1207/s15430421tip4102_8

Pajares, F. (2006). SE. In W. A. Darity (Ed.), International Encyclopedia of the Social Sciences (2nd ed.). Santa Barbara, CA: ABC-Clio. [Online] Retrieved on October 11, 2006, from http://des.emory.edu/mfp/MSCPs2006FallComp.html.

Pajares, F. (2007a). Empirical Properties of a Scale to Assess Writing SE in School Contexts [Electronic version]. Measurement and Evaluation in Counseling and Development, 39, 239-249.

Pajares, F. (2007b). Motivational role of SE beliefs in self-regulated learning. In D. H. Schunk \& B. J. Zimmerman (Eds.), Motivation and self-regulated learning: Theory, research, and application (pp. 111-140). New York: Erlbaum.

Pajares, F., \& Graham, L. (1999). SE, motivation constructs, and mathematics performance of entering middle school students. Contemporary Educational Psychology, 24, 124-139. http://dx.doi.org/10.1006/ceps.1998.0991

Pintrich, P., \& Schunk, D. H (1996). Motivation in education: Theory, research \& application, Ch. 3. Englewood Cliffs, NJ: Prentice-Hall. [Online] Retrieved on March 27, 2006 from http://www.des.emory.edu/mfp/PintrichSchunk1996.html

Schunk, D. H. (1984). Enhancing SE and achievement through rewards and goals: Motivational and informational effects. Journal of Educational Research, 78, 29-34.

Schunk, D. H. (1991). SE and academic motivation. Educational Psychologist, 26(3\&4), 207-231. http://dx.doi.org/10.1080/00461520.1991.9653133

Schunk, D. H. (1996). Goal and self-evaluative influence during children's cognitive skill learning. American Educational Research Journal, 33, 359-382.

Schunk, D. H., \& Hanson, A. R. (1985). Peer models: Influence on children's SE and achievement. Journal of Educational Psychology, 77(3), 313-322. http://dx.doi.org/10.1037/0022-0663.77.3.313 


\section{Al Macrothink}

International Journal of Education

ISSN 1948-5476

2012, Vol. 4, No. 1

Schunk, D. H., \& Pajares, F. (2002). The development of academic SE. In A. Wigfield \& J. Eccles (Eds.). Development of achievement motivation (16-31). San Diego: Academic Press. [Online] Retrieved April 3, 2006, from http://www.des.emory.edu/mfp/SchunkPajares

Schunk, D.H. (1983). Developing children's SE and skills: The roles of social comparative information and goal setting. Contemporary Educational Psychology, 8, 76-86. http://dx.doi.org/10.1016/0361-476X(83)90036-X

Schunk. D.H. (1987). Peer models and children's behavioral change. Review of Educational Research, 57, 149-174.

Siegel, R. G., Galassi, J. P., \& Ware, W. B. (1985). A comparison of two models for predicting mathematics performance: Social learning versus math aptitude-anxiety. Journal of Counselling Psychology, 32, 531-538. http://dx.doi.org/10.1037/0022-0167.32.4.531

Stevens, T., Olivarez, A., Lan, W. Y., \& Runnels, M. K. T. (2004). Role of mathematics SE and motivation in mathematics performance across ethnicity. The Journal of Educational Research, 97(4), 208 - 222. http://dx.doi.org/10.3200/JOER.97.4.208-222

Usher, E. L., \& Pajares, F. (2006). Sources of academic and self-regulatory efficacy beliefs of entering middle school students [Electronic version]. Contemporary Educational Psychology, 31, 125-141. http://dx.doi.org/10.1016/j.cedpsych.2005.03.002

Valiante, G., \& Pajares, F. (1999). The inviting/disinviting index: Instrument validation and relation to motivation and achievement [Electronic version]. Journal of Invitational Theory and Practice. 6(1), 28-46.

Zimmerman, B. J. (1989). A social cognitive view of self-regulated academic learning. Journal of Educational Psychology, 81(3). Retrieved on March 12, 2005, from PsycARTICLES database.

Zimmerman, B. J., \& Martinez-Pons, M. (1990). Student differences in self-regulated learning: Relating grade, sex, and giftedness to SE and strategy use. Journal of Educational Psychology, 82(1), 51-59. http://dx.doi.org/10.1037/0022-0663.82.1.51

Zimmerman, B. J., Bandura, A., \& Martinez-Pon, M. (1992). Self-motivation for academic attainment: The role of SE beliefs and personal goal setting. American Educational Research Journal, 29(3), 663-676.

Zimmerman, B.J., \& Bandura, A. (1994). Inppact of self-regulatory influences on writing course attainment. American Educational Research Journal, 31, 845-862.

\section{Copyright Disclaimer}

Copyright reserved by the author(s).

This article is an open-access article distributed under the terms and conditions of the Creative Commons Attribution license (http://creativecommons.org/licenses/by/3.0/). 